\title{
STRATEGI KEPALA SEKOLAH DALAM PEMBINAAN IKLIM DAN BUDAYA SEKOLAH DI SDI TARUNA SURABAYA
}

\author{
Lailatu Zahroh \\ STAI Taruna Surabaya \\ (lailatuzahro@gmail.com)
}

\begin{abstract}
Abstrak: Kepala sekolah merupakan pemimpin pendidikan tingkat satuan pendidikan, yang harus bertanggung jawab terhadap maju mundurnya sekolah yang dipimpinnya. Dia dituntut untuk memiliki kemampuan manajemen maupun kepemimpinan, agar dapat mengembangkan dan memajukan sekolahnya secara efektif, efisien, mandiri, produktif dan akuntabel. Dengan mengambil topik "Strategi Kepala Sekolah dalam Pembinaan Iklim dan Budaya Sekolah di SDI Taruna Surabaya". Peneliti berusaha untuk mengungkap strategi kepala SDI Taruna Surabaya dalam pembinaan iklim dan budaya sekolah di SDI Taruna Surabaya beserta faktor pendukung dan penghambatnya. Untuk mengungkap masalah tersebut digunakan teknik penelitian: 1) observasi, digunakan untuk mengetahui kondisi SDI Taruna Surabaya dan aktifitas di dalamnya, 2) interview, digunakan untuk menggali data terkait dengan strategi kepala sekolah dalam Pembinaan Iklim dan budaya Sekolah di SDI Taruna Surabaya, beserta faktor pendukung dan penghambatnya. 3) Dokumentasi, untuk mendapat data terutama terkait dengan berbagai instrumen dan hasil tes yang digunakan di SDI Taruna, dan 4) Focus Group Discussion untuk memvalidasi temuan penelitian dan upaya pencarian solusi atas persoalan yang ada.

Berdasarkan rumusan masalah dan dengan menggunakan teknik pengumpulan data di peroleh hasil: 1) Strategi yang digunakan untuk meningkatkan kualitas pembelajaran, yang dapat diidentifikasi oleh peneliti antara lain adalah: penerapan kurikulum adaptif, mendongkrak prestasi sekolah (siswa maupun guru) pelibatan masyarakat sekitar dan pendayagunaan potensi lokal, penyediaan sarana-prasarana atau fasilitas layanan, dan menjalin kerjasama dengan pihak luar . 2) Beberapa faktor pedukung adalah: adanya kerjasama yang baik dengan para guru dan tenaga kependidikan berdasarkan kompetensinya, kedisiplinan para civitas akademik SDI Taruna, sarana prasarana yang memadai, siswa-siswi yang kooperatif dalam menerima tata tertib sekolah, kegiatankegiatan ekstrakurikuler, jaringan kerjasama dengan pihak luar, dukungan masyarakat sekitar. 3) Adapun kendala yang dihadapi antara lain: ketika ada peluang bagi siswa untuk mengikuti kegiatan di luar daerah karena kompetensi yang dimiliki, terkadang tidak diizinkan oleh orang tuanya. Ada yang karena tidak punya biaya untuk uang saku anaknya, ada yang karena keberatan secara psikologis, dan ada yang karena alasan lain.
\end{abstract}

Kata Kunci : Strategi Kepala Sekolah, Pembinaan Iklim dan Budaya Sekolah

72 | Lailatu Zahroh, Strategi Kepala Sekolah dalam Pembinaan Iklim dan Budaya Sekolah di SDI Taruna Surabaya P a g e 


\section{A. Latar Belakang Masalah}

Sukses tidaknya pendidikan dan pembelajaran di sekolah sangat dipengaruhi oleh kemampuan kepala sekolah dalam mengelola setiap komponen sekolah. Pengembangan sekolah yang efektif, efisien, produktif dan akuntabel perlu ditunjang oleh perubahan berbagai aspek pendidikan lainnya, termasuk iklim sekolah (school climate).Perubahan iklim sekolah perlu dilakukan untuk merespons kondisi pendidikan dewasa ini yang semakin terpuruk.Hal ini lebih diperkuat lagi dengan perubahan-perubahan mendasar dalam berbagai aspek kehidupan, yang menuntut penyesuaian pendidikan, dan iklim sekolah yang kondusif yang menunjang terhadap pembelajaran yang bermakna. Dalam kerangka inilah perlunya manajemen kepemimpinan kepala sekolah dalam menciptakan iklim dan budaya sekolah yang kondusif, untuk mencapai tujuan pendidikan secara efektif, efisien, mandiri, produktif dan akuntabel. ${ }^{1}$

Menurut Reynold, dalam sekolah efektif, perhatian khusus diberikan kepada penciptaan dan pemeliharaan iklim dan budaya yang kondusif untuk belajar ${ }^{2}$ Iklim dan budaya sekolah yang kondusif ditandai dengan terciptanya lingkungan belajar yang aman, nyaman, dan tertib, sehingga pembelajaran dapat berlangsung secara efektif. Iklim dan budaya sekolah yang kondusif sangat penting agar siswa merasa senang dan bersikap positif terhadap sekolahnya, agar guru merasa dihargai, serta agar orang tua dan masyarakat merasa diterima dan diberikan ${ }^{3}$.Hal ini dapat terjadi melalui penciptaan norma dan kebiasaan yang positif, hubungan dan kerja sama yang haromonis yang didasari oleh sikap saling menghormati. Selain itu, iklim dan budaya sekolah yang kondusif mendorong setiap warga sekolah untuk bertindak dan melakukan sesuatu yang terbaik yang mengarah pada prestasi siswa yang tinggi.

Iklim dan budaya sekolah juga berkaitan dengan pemupukan harapan untuk berprestasi pada semua warga sekolah. Penelitian Wite dan Walsh ${ }^{4}$ mengungkapkan adanya hubungan yang signifikan antara harapan yang tinggi untuk berprestasi dan

\footnotetext{
${ }^{1}$ E.Mulyasa, Manajemen \& Kepemimpinan Kepala Sekolah (Jakarta: Bumi Aksara, 2012), hlm 89

${ }^{2}$ Reynold, dalam E.Mulayasa, Manajemen....., hlm 90

${ }^{3}$ Townsend, dalam E.Mulyasa, Manajemen........ hlm 91

${ }^{4}$ John White, Educational and The Good Life (London: Educational Studies Kogan, 1990).
}

73 | Lailatu Zahroh, Strategi Kepala Sekolah dalam Pembinaan Iklim dan Budaya Sekolah di SDI Taruna Surabaya P a g e 
prestasi akademik siswa. Karakteristik ini berkenaan dengan penciptaan etos positif yang dapat mendorong siswa berprestasi. Harapan yang tinggi yang ditransimisikan ke dalam kelas berperan dalam meningkatkan ekspektasi siswa terutama keinginan untuk meningkatkan prestasi akademik mereka. Harapan dan standar untuk berprestasi yang tinggi juga perlu bagi para staf sekolah yang ditandai dengan adanya: (1) keyakinan bahwa semua siswa dapat belajar, (2) tanggung jawab yang tinggi bagi pembelajaran siswa, (3) harapan yang tinggi akan pekerjaan yang berkualitas tinggi, (4) persyaratan promosi dan perjenjangan, dan (5) pemberian perhatian pribadi kepada siswa perorangan.

Pembinaan iklim dan budaya sekolah yang kondusif perlu sekali diciptakan, karena dewasa ini perkembangan ilmu pengetahuan, teknologi, dan seni berlangsung setiap saat, Perkembangan penduduk yang cepat membutuhkan pelayanan pendidikan yang besar. Sumber daya manusia yang berkualitas merupakan modal dasar sekaligus menjadi kunci keberhasilan pembangunan nasional. ${ }^{5}$

Sekolah-sekolah Islam di Indonesia masih banyak yang rendah mutunya. Kata "rendah" ditemukan dengan cara membandingkan mutu sekolah-sekolah Islam (seperti sekolah Muhammadiyah dan Nahdatul Ulama) dengan mutu sekolah yang diasuh oleh umat yang beragama lain, ${ }^{6}$ dan bukan rahasia lagi kalau pendidikan yang dikelola NU sedikit tertinggal dari sekolah-sekolah milik organisasi lain; apalagi dengan unit-unit pendidikan milik agama lain. Kesan kalah langkah itu, sekalipun tidak banyak terungkap namun banyak orang yang merasakannya. Memang fakta yang berbicara tidak bisa dipungkiri oleh kata-kata. ${ }^{7}$ Itulah kesan umum yang muncul di tengah masyarakat, meskipun kesan itu tidak seratus persen benar, karena NU juga memiliki banyak sekolah favorit dan berkualitas; satu diantaranya SDI Taruna Surabaya.

SDI Taruna Surabaya yang beralamat di J1 KalirungkutMejoyo I1-2 Surabaya. Fasilitas yang dimiliki sekolah ini jauh berbeda dengan gambaran sekolah Islam pada umumnya, diantaranyaPerpustakaandenganbuku yang cukupbanyak, Laboratorium IPA, LaboratoriumMatematikadanLaboratoriumKomputer, ruang BP/BK danruang $\mathrm{UKS}^{8}$

\footnotetext{
${ }^{5}$ E.Mulyasa, Manajemen Kepemimpinan....., hlm 93

${ }^{6}$ Ahmad Tafsir, Ilmu Pendidikan dalam Perspektif Islam( Bandung: Remaja Rosdakarya, 1991), hlm 107

7 Majalah Nahdlatul Ulama, Aula Bulan September, (Surabaya: Pengurus Wilayah Nahdlatul Ulama Jawa Timur, 2001), hlm 60

${ }^{8}$ Sumber : Dokumentasi SDI Taruna Surabaya 2017
}

74 | Lailatu Zahroh, Strategi Kepala Sekolah dalam Pembinaan Iklim dan Budaya Sekolah di SDI Taruna Surabaya P a g e 
Jurnal Keislaman, Vol 3, No 1

Sampai tahun pelajaran 2017/2018 ini SDI Taruna Surabaya telah memperoleh prestasi di berbagai bidang baikprestasiakademikmaupun non akademik:

1. PrestasiTahun $2015 / 2016$

a. Juara 10 terbaikPondokRomadlontingkat SD se Kota Surabaya

b. Juara II MTQ Putra tingkatanak-anak se-Surabaya Timur

c. Juara III MTQ Putritingkatanak-anak se Surabaya Timur

d. Juara 10 terbaik Baca PuisiPentasSeni SD se KecamatanRungkut

e. Juara I PidatoPentas PAI se-JawaTimur

f. Juara I PidatoBahasa Indonesia se-Kota Surabaya

g. Juara I Dacil se-Kota Surabaya

h. Juara II PidatoBahasa Indonesia se-Kota Surabaya

i. JuaraHarapan II PondokRamadlan Tingkat SD se-Kota Surabaya

j. Juara I Dacil se- JawaTimur

k. Juara III GerakJalanbershalawat

\section{PrestasiTahun 2016/2017}

a. Juara I Putra PondoikPesantrenTerpadu SD/MI se-KecamatanRungkut

b. Juara II Putra PondokRamadlanTerpadu SD/MI s-KecamatanRungkut

c. Juara II PutriPondokRamadlanTerpadu SDMI se-KecamatanRungkut

d. Juara III Divisi Compound Panahananar SD se-Kota Surabaya

e. Juara II LombaKaligrafi Tingkat SD se-Kota Suarabaya

f. Juara II Lomba MTQ Tingkat SDMI ae-KecamatanRungkut

g. Juara III LombaKaligrafi Tingkat SDMI se-KecamatanRungkut

h. Juara II LombaGgiSehat Dies Natalis ke-46 Ubaya Surabaya

\section{Prestasitahun $2017 / 2018$}

a. Juara I Lomba MTQ SD/MI se-KecamatanRungkut

b. Juara I LOmbaKaligrafi SD/MI se-KecamatanRungkut

c. Juara I LombaSenamCuciTangan Global Handwashing Day JawaTimur

d. Juara I LombaKaligrafi SD/MI Tingkat Kota Surabaya 
e. JuaraHarapan III Pawai Muharram se KecamatanRungkut

f. Juara III Divisi Compound KejuaraanPanahan se kota Surabaya

g. JuRUMumPerkemmahanPenggalangTahun 2015 KwartirRungkut

h. JuR I BereguKejuaraanPanahan Tingkat JawaTimur

i. Juara II KejuaraanPanahan Tingkat JawaTimur ${ }^{9}$

Kesungguhan SDI Taruna Surabaya telah membuahkan hasil. Pada saat ini juga telah banyak perubahan selain peningkatan sarana prasarana sekolah dan materi/metode pembelajaran juga peningkatan kualitas SDM pendidik dan tenaga kependidikan. SDI Taruna melaksanakan kegiatan training metode dan strategi pembelajaran untuk guruguru dan ICT mata pelajaran yang hasilnya untuk Proses Belajar Mengajar (PBM) di kelas.

Melihat kemajuan yang dicapai oleh SDI Taruna dan banyaknya prestasi akademik maupun non akademik yang diraih oleh sekolah NU ini yang pastinya tidak bisa dilepaskan dari strategi kepala sekolah, penulis sangat ingin mengangkatnya dalam penelitian. Berdasarkan uraian dalam latar belakang penelitian diatas serta didorong oleh rasa memiliki (sense of belonging) untuk ikut serta mengembangkan dan memajukan lembaga pendidikan Islam di Indonesia, maka dalam penelitian ini penulis mengambil judul "Strategi Kepala Sekolah dalam Pembinaan Iklim dan Budaya Sekolah di SDI Taruna Surabaya”.

\section{B. Tujuan Penelitian}

1. Untuk mengetahui strategi kepala sekolah dalam pembinaan iklim dan budaya sekolah di SDI Taruna Sarabaya

2. Untuk mengetahui faktor pendukung strategi kepala dalam pembinaan iklim dan budaya sekolah di SDI Taruna Sarabaya

3. Untuk mengetahui faktor penghambat strategi kepala dalam pembinaan iklim dan budaya sekolah di SDI Taruna Sarabaya

\footnotetext{
${ }^{9}$ Sumber: Dokumen SDI Taruna Surabaya 2017

76 | Lailatu Zahroh, Strategi Kepala Sekolah dalam Pembinaan Iklim dan Budaya Sekolah di SDI Taruna Surabaya P a g e
} 


\section{Metode Penelitian}

Persoalan dalam penelitian ini adalah mengenai "Strategi Kepala Sekolah dalam Pembinaan Iklim dan Budaya Sekolah di SDI Taruna Surabaya”. Penelitian ini berusaha menggambarkan fenomena pada kondisi alamiah, secara holistik, kompleks, dinamis dan bermakna. Pendekatan seperti ini dalam metodologi riset disebut pendekatan kualitatif atau naturalistic. ${ }^{10}$ Jadi Jenis penelitian ini termasuk penelitian kualitatif-naturalistik, karena dilakukan dalam situasi yang wajar (natural setting). ${ }^{11}$

Menurut Yin, penelitian yang berusaha menjawab pertanyaan tentang 'bagaimana' lebih bersifat eksplanatori dan mengarah pada penggunaan case study sebagai strateginya. ${ }^{12}$ Untuk itu maka rancangan penelitian ini menggunakan rancangan studi kasus. Pendekatan kualitatif yang digunakan dalam penelitian ini adalah pendekatan rasionalitas fenomenologis. ${ }^{13}$

Apabila dilihat dari segi metode, penelitian ini menggunakan metode deskriptif. Penggunaan metode deskripsi sebagai upaya mendapatkan dan menyampaikan faktafakta dengan jelas dan teliti. Deskripsi merupakan suatu generalisasi, yaitu suatu pengamatan atas gejala-gejala yang tidak hanya untuk keperluan kejadian-kejadian itu sendiri, tetapi untuk memahami gejala yang lebih luas lagi. Sesuai dengan karakteristik, maka penelitian ini menggunakan tiga langkah, yaitu: 1. Description, 2. Reduction, 3. Selection. ${ }^{14}$

Data yang dikumpulkan dalam penelitian ini dikelompokkan dalam data primer dan data sekunder. Data primer bersumber dari orang pertama dan orang yang mengetahui secara jelas dan rinci mengenai masalah yang sedang diteliti. Karakteristik dari data primer ialah dalam bentuk kata-kata atau ucapan lisan dan prilaku / tindakan manusia. ${ }^{15}$ Informan yang lain sebagai informan tambahan atau pelengkap adalah pendidik dan tenaga kependidikan di SDI Taruna Surabaya. Data yang terkumpul akan dicatat melalui catatan lapangan (field note) secara tertulis, dan pencatatan tersebut

\footnotetext{
${ }^{10}$ Lincoln \& Guba, Naturalistic Inquiry (Beverly Hill: CA, SAGE Publications, Inc., 1985)

${ }^{11}$ Bogdan dan Steven, Introduction to Qualitative Research; A Phenomenological Approach to The Social Sciences (New York: John Wiley \& Sons Inc., 1975).

${ }^{12}$ Robert Yin, Case Study Research (London: Sage Publications, 1989)

${ }^{13}$ Noeng Muhadjir, Metodologi Penelitian Kualitatif (Yogyakarta: Rake Sarasin, 2000), hlm 12.

${ }^{14}$ Nasution, Metodologi Penelitian Naturalistik Kualitatif (Bandung: Transito, 1996)

${ }^{15}$ Lexy J. Moleong, Metodologi Penelitian Kualitatif, Cet. III (Bandung: Remaja Rosda Karya, 1991), hlm 112

77 | Lailatu Zahroh, Strategi Kepala Sekolah dalam Pembinaan Iklim dan Budaya Sekolah di SDI

Taruna Surabaya P a g e
} 
merupakan hasil dari gabungan proses bertanya, mendengar dan melihat.Data sekunder berasal dari dokumen-dokumen berupa catatan-catatan, rekaman dan foto-foto yang dapat digunakan sebagai data pelengkap.

Subjek informan ditentukan secara snowballing. Teknik ini digunakan untuk mencari informasi secara terus menerus dari informan satu ke informan lainnya, sehingga data yang diperoleh semakin banyak, lengkap dan mendalam. Penggunaan teknik snowballing dihentikan bila data yang diperoleh dianggap telah jenuh. Selanjutnya hasil atau temuan penelitian tentang Strategi Kepala Sekolah dalam Pembinaan Iklim dan Budaya Sekolah di SDI Taruna Surabaya dipadukan dalam sebuah analisis. Berdasarkan hasil analisis disusunlah sebuah kerangka temuan penelitian yang bersifat kualitatif. ${ }^{16}$ Meskipun penentuan informan menggunakan teknik snowballing, tapi diberikan kriteria tertentu pada informan yang dipilih. Subjek dan informan ${ }^{17}$ yang dipilih dalam penelitian ini adalah: Kepala Sekolah, Waka Kurikulum, guru dan siswa SDI Taruna Surabaya.

Teknik pengumpulan data dalam penelitian ini dilakukan dengan jalan: observasi, wawancara, dokumentasi, fokus group discussion. Data-data yang terkumpul dianalisis dengan teknik deskriptif-kualitatif. ini dimaksudkan sebagaiprosesmenyusun, mengkatagori data, dan mencaripolaatau tema denganmaksuduntukmemahamimaknanya. Analisis data merupakanprosesbertanya-menemukan (questiondiscovery). Prosedurdalamanalisis data yang disarankanoleh Miles dan Hubermanadalah: reduksi data, displaydata, kesimpulan sementara dan verifikasi. ${ }^{18}$

\section{Hasil Penelitian}

\section{Strategi Kepala SDI Taruna dalam Pembinaan Iklim dan Budaya Sekolah}

Dalam pembinaan iklim dan budaya sekolah untuk meningkatkan kualitas pembelajaran, beberapa strategi yang dapat dilakukan oleh kepala sekolah antara lain

\footnotetext{
${ }^{16}$ Pamela Maycut \& Richard House, Beginning, Qalitative Researc, A Philosophy and Practical Guide, (Wasington D.C: The Falmer Press Teachers Library, 1994)

${ }^{17}$ Informan adalah orang yang dimanfaatkan untuk memberikan informasi tentang situasi dan kondisi latar penelitian. Lihat Lexy J. Moleong, Metodologi Penelitian Kualitatif, Cet. III, (Bandung: Remaja Rosda Karya, 1991), hlm 90.

${ }^{18}$ Miles \& Huberman, Qualitative Data Analysis (London: SAGE Publications, 1984), hlm 20.
}

78 I Lailatu Zahroh, Strategi Kepala Sekolah dalam Pembinaan Iklim dan Budaya Sekolah di SDI

Taruna Surabaya P a g e 
berupa program akselerasi, mendongkrak prestasi belajar, mendayagunakan lingkungan sekitar sekolah dan melibatkan masyarakat, dan mengembangkan program kewirausahaan.

Dalam konteks SDI Taruna, ia termasuk lembaga pendidikan atau sekolah yang selalu berupaya dalam meningkatkan kualitas pembelajarannya melalui pembinaan iklim dan budaya sekolah. Oleh karena itu, dalam lokalitas sekolah di KecamatamRungkut, bahkan Surabaya termasuk dalam kategori sekolah yang unggul dan kompetitif.

SDI Taruna merupakan sekolah yang berafiliasi dengan Nahdhatul Ulama (NU) yang unggul dibanding sekolah-sekolah NU yang lain di wilayahRungkut. Menurut Kepala Sekolah (Kasek) SDI Taruna, ZainalMahmudi, SAg, keunggulan SDI Taruna tidak lepas dari sejarah pendiriannya. Dengan demikian, keunggulan SDI Taruna saat ini memang sudah diupayakan sejak berdirinya. Para pelaku pendidikan di SDI Taruna saat ini hanya menlanjutkan dan menjaga serta mengembangkan nilai-nilai keunggulan yang sudah dirintis sejak pendiriannya. Pendiri SDI Taruna memang sejak awal berkomitmen untuk menyelenggarakan pendidikan yang berkualitas dan unggul.

Dalam perjalanannya, untuk menjaga kualitas pembelajaran di SDI Taruna, yang dilakukan adalah pembinaan iklim dan budaya sekolah. Dalam hal kurikulum, iklim dan budaya sekolah yang dikembangkan adalah kurikulum adaptif, yang di dalamnya mengandung unsur kurikulum Depagdan kurikulum nasional.

Peningkatan mutu pendidikan menjadi salah satu keseriusan SDI Taruna . Peningkatan mutu pendidikan tidak terlepas dari kurikulum yang digunakan SDI Taruna. Bekal dari pelatihan, workshop dan seminar tentang pengembangan kurikulum adaptif, MGMP guru mapel berusaha mengembangkan kurikulum yang ada di SDI Taruna.

SDI Taruna juga memberikan materi matrikulasi yang diberikan di kelas pagi. Materi matrikulasi berisi pembekalan agama/Diniyah. Materi tambahan ini bertujuan memberikan pembekalan dan ketrampilan tentang keagamaan. 
SDI Taruna dari tahun ke tahun telah mendapat kepercayaan dari masyarakat luas khususnya masyarakat di KecamatanRungkut. Dukungan dan kepercayaan dari masyarakat itulah yang mengantar SDI Taruna menjadi Sekolah Unggul. SDI Taruna tidak mau mengecewakan masyarakat dan berusaha mempertahankan kepercayaan yang sudah ada.

Dalam menjalin hubungan dengan masyarakat terutama wali murid, strategi yang dilakukan SDI Taruna antara lain: wali murid dlibatkan dalam acara-acara tour mendampingi anaknya. Sementara kegiatan anak-anak atau siswa dalam bentuk apapun, ketika ada kaitannya dengan program sekolah, pihak guru selalu mengawal. Hal ini menambah tingkat kepercayaan wali murid kepada sekolah. Kegiatan-kegiatan siswa di luar yang menjadi program sekolah, pihak sekolah selalu memberitahukan kepada wali murid. Kalau wali murid mengizinkan anaknya terlibat, ya diikutkan. Kalau orang tua murid keberatan anaknya ikut, ya pihak sekolah tidak memaksa. ${ }^{19}$

Dengan demikian, strategi yang juga dilakukan SDI Taruna dalam membina iklim dan budaya sekolah untuk meningkatkan kualitas pembelajaran adalah dengan memanfaatkan kepercayaan masyarakat yang tinggi terhadap keberadaan sekolah ini. $^{20}$ Kepercayaan masyarakat dimanfaatkan untuk semakin menata diri demi kemajuanya. Animo masyarakat untuk menyekolahkan anaknya ke SDI Taruna semakin meningkat dari tahun ke tahun. Hal ini terindikasi dari jumlah pendaftar menjadi siswa SDI Taruna yang semakin meningkat.

Dalam hal implementasi kurikulum, dan dalam segala aktifitas sekolah, SDI Taruna selalu menerapkan tiga (3) langkah, yakni rencana (plan), tindakan (action), dan perubahan (change). SDI Taruna.

Dengan demikian, strategi pembinaan iklim dan budaya sekolah demi meningkatkan kualitas pembelajaran yang dilakukan oleh SDI Taruna adalah mendongkrak prestasi guru, tenaga kependidikan dan siswa. Bagi mereka yang berprestasi, maka akan diberikan award (penghargaan) dari pihak sekolah. Sementara bagi mereka yang tidak disiplin dan tidak tertib administratif, akan diberikan sanksi (punishment). Misalnya, seorang wali kelas, jika tidak menunjukkan prestasi, atau jika

\footnotetext{
${ }^{19}$ Ainur Rofiq (Waka Humas SMA Khadijah), Wawancara pada 14 Januari 2015.

${ }^{20}$ Muchammad Mas'ud (Kepala Sekolah SMA Khadijah), Wawancara pada 13 Januari 2015.

80 | Lailatu Zahroh, Strategi Kepala Sekolah dalam Pembinaan Iklim dan Budaya Sekolah di SDI Taruna Surabaya P a g e
} 
rekam kinerjanya tidak maksimal, maka akan lepas jabatannya sebagai wali kelas, dan hanya mengajar saja. ${ }^{21}$

Dalam rangka mendongkrak prestasi ini, saat ini telah banyak perubahan selain peningkatan sarana prasarana sekolah dan materi/metode pembelajaran juga peningkatan kualitas SDM pendidik dan tenaga kependidikan. SDI Taruna melaksanakan kegiatan training metode dan strategi pembelajaran untuk guru-guru semua guru mata pelajaran yang hasilnya untuk Proses Belajar Mengajar (PBM) di kelas.

SDI Taruna juga telah menjalin kerjasama dengan Lembaga Pendidikan dan Pelatihan dalam rangka meningkatkan mutu SDM pendidik dan tenaga kependidikan; juga menjalin kerjasama dengan Lembaga Pendidikan Tinggi di Indonesia yang diharapkan dapat meningkatkan kualitas pendidik sehingga berpengaruh signifikan khususnya terhadap perkembangan kualitas pembelajaran di SDI Taruna .

SDI Taruna juga telah menjalin kerjasama dengan STAI Taruna Surabaya khususnya Prodi PAI dan PGMI. Perubahan-perubahan menuju perbaikan dan peningkatan kualitas di berbagai bidang tampak nyata dan dapat dirasakan oleh siswa maupun guru dan karyawan SDI Taruna. Harapannya, SDI Taruna semakin berkualitas dan terdepan dalam menjamin mutu dan menjalin kerjasama dengan Institusi Pendidikan agar dapat menghasilkan anak didik serta alumni yang memiliki kemampuan keilmuan serta tetap berteguh hati dalam keimanan dan ketaqwaan.

Melalui upaya mendongkrak prestasi ini, maka banyak pengasuh SDI Taruna yang telah berhasil mencapai prestasi yang membanggakan di berbagai bidang.

Hal yang dikembangkan lagi terkait dengan iklim dan budaya di SDI Taruna ini adalah budaya santun dan iklim pembelajaran yang kondusif. Budaya santun ini sangat dikedepankan di SDI Taruna . Kedisiplinan juga sangat ditekankan bagi guru dan siswa di SDI Taruna . Bagi guru atau siswa yang datanganya lebih dari jam 6.30, maka dia sudah terhalang masuk sekolah karena pagar sudah ditutup. Dia bisa masuk sekolah ketika pagar dibuka sekitar jam $7 .^{22}$

\footnotetext{
${ }^{21}$ Nur Mantoko (Kepala Unit Penjamin Mutu-UPM SMA Khadijah), Wawancara pada 14 Januari 2015.

${ }^{22}$ Nur Mantoko (Kepala Unit Penjamin Mutu-UPM SMA Khadijah), Wawancara pada 14 Januari 2015.
}

81 | Lailatu Zahroh, Strategi Kepala Sekolah dalam Pembinaan Iklim dan Budaya Sekolah di SDI Taruna Surabaya P a g e 
Budaya shalat berjamaah juga diterapkan di SDI Taruna . Jamaah shalat Dhuhur dan Ashar dilakukan oleh semua siswa dengan tertib tanpa ada paksaan dari gurunya. Pendekatan yang dipakai sekolah dalam menanamkan budaya santun dan disipilin -salah satunya- adalah dengan pendekatan materi moral keagamaan. Mata pelajaran agama di SDI Taruna berjumlah 12 jam pelajaran per-mingggunya. ${ }^{23}$ Ini cukup besar dibanding SD/MI lain, yang biasanya hanya 2-6 jam mata pelajaran agama. Senin sampai Kamis siswa dapat matrikulasi agama/Diniyah. Jama'ah shalat dhuha dilakukan pada setiap hari Sabtu. Jadi iklim dan budaya spiritual keagamaan juga menjadi arus yang dikedepankan di SDI Taruna .

Pelajaran agama ditunjang dengan pelajaran nahwu, sharaf, tajwid, danilmu alat yang lain. Setiap akhir semester diadakan studium general. Anak-anak diberi kesempatan untuk presentasi dan kemudian dibahas bersama.Awal semester ganjil biasanya diberikan matrikulasi agama secara teoritis dan praktis. Kemudian belajar tartil Al-Quran selalu difasilitasi pada jam pertama (6.30). ${ }^{24}$

Di kelas ada guru ngaji, wali kelas, dansiswa. Kamis selalu diberikan pembacaan yasin dan tahlil, dan yang memimpin adalah siswa. Dalam pembacaan tartil Al-Quran, anak-anak menerapkan sistem movingclass, disesuaikan dengan tingkat kefasihannya.

Bagi guru-guru yang sedang ada kegiatan di luar, maka jam mengajarnya diisi oleh guru piket yang sudah dipersiapkan oleh pihak sekolah. Jamaah shalat dhuhur dilakukan setiap hari ketika masuk sekolahdisetting seperti shalat Jum'at. ${ }^{25}$

\section{Faktor Pendukung Kepala SDI Taruna dalam Pembinaan Iklim dan Budaya Sekolah}

Beberapa faktor pedukung kepala SDI Taruna dalam pembinaan iklim dan budaya sekolah antara lain adalah: adanya kerjasama yang baik dengan para guru dan tenaga kependidikan sesuai kompetensinya, kedisiplinan para civitas akademik SDI Taruna, sarana prasarana yang memadai, siswa-siswi yang kooperatif dalam

\footnotetext{
${ }^{23}$ Muchammad Mas'ud (Kepala Sekolah SMA Khadijah), Wawancara pada 13 Januari 2015.

${ }^{24}$ Syifa'ul Khoir (Guru SMA Khadijah), Wawancara pada 04 Februari 2015.

${ }^{25}$ H. Edy Kusnianto (Waka Kesiswaan SMA Khadijah), Wawancara pada 14 Januari 2015.
}

82 | Lailatu Zahroh, Strategi Kepala Sekolah dalam Pembinaan Iklim dan Budaya Sekolah di SDI Taruna Surabaya P a g e 
menerima tata tertib sekolah, kegiatan-kegiatan ekstrakurikuler, jaringan kerjasama dengan pihak luar, dukungan masyarakat sekitar, dan unit penjamin mutu.

Adanya kerjasama yang baik antar guru dan tenaga kependidikan membuat kebijakan-kebijakan yang mengarah pada pembinaan iklim dan budaya sekolah di SDI Taruna dapat terimplementasi dengan baik. Kedisiplinan para civitas akademik SDI Taruna juga menjadi faktor pendukung penting bagi tercapainya pembinaan iklim dan budaya sekolah untuk meningkatkan kualitas pembelajaran dan mutu sekolah.

Sarana prasarana atau fasiitas layanan sekolah juga menjadi faktor penting dalam mendukung pembinaan iklim dan budaya sekolah untuk meningkatkan kualitas pembelajaran dan mutu SDI Taruna . Fasilitas layanan yang dimiliki SDI Taruna sangat banyak dan memadai.

Kegiatan Ekstra Kurikuler: Qiro'ah, Banjari, Paskibraka, Teater / Drama, Seni Rupa, Mewarnai, Menari, Pramuka, Memanah, Kaligrafi, Pidato dan Musik.

\section{Kendala Kepala SDI Taruna dalam Pembinaan Iklim dan Budaya Sekolah}

Dalam pembinaan iklim dan budaya sekolah di SDI Taruna, kendala yang dihadapi relatif tidak begitu dominan. Meskipun ada kendala, namun kendala-kendala yang ada relatif dapat teratasi. Kendala yang dihadapi oleh SDI Taruna antara lain: ketika ada peluang bagi siswa untuk mengikuti kegiatan di luarkota karena kompetensi yang dimiliki, terkadang tidak diizinkan oleh orang tuanya. Alasan orang tua tidak mengizinkan macam-macam. Ada yang karena tidak punya biaya untuk uang saku anaknya, ada yang karena keberatan secara psikologis, dan ada yang karena alasan lain. $^{26}$

Ada juga yang orang tuanya menginginkan agar anaknya dapat didelegasi ke luar kota, tetapi kompetensi anaknya yang tidak mendukung. Beberapa orang tua yang ingin anaknya berangkat ke luar kota umumnya berangkat dari kemampuan orang tua secara finansial. Tetapi kendalanya terkadang IQ anaknya yang tidak mendukung untuk bisa berangkat.

\footnotetext{
${ }^{26}$ Muchammad Mas'ud (Kepala Sekolah SMA Khadijah), Wawancara pada 13 Januari 2015.
}

83 | Lailatu Zahroh, Strategi Kepala Sekolah dalam Pembinaan Iklim dan Budaya Sekolah di SDI Taruna Surabaya P a g e 
Kendala lain yang terkadang dihadapi oleh SDI Taruna dalam pembinaan iklim dan budaya sekolah adalah sedikit ada resistensi dari guru ketika ada penilaian untuk guru dari KepalaSekolah. ada guru yang hasil penilaiannynya tidak memuaskan, komplain kepada pimpinan. Bentuk komplainnya klasik: mengapa tidak percaya pada kinerja guru, sehingga harus dilakukan penilaian segala? Hal itu dapat diatasi oleh pihak pimpinan bahwa penilaian kinerja guru dilakukan demi mengontrol kualitas pembelajaran dan mutu sekolah. ${ }^{27}$

Penilaian terhadap kinerja guru dilakukan bukan untuk maksud yang buruk, tetapi untuk maksud yang baik dan mulia, yakni untuk mengontrol kualitas (quality control). Setinggi apapun kualitas sebuah lembaga, kalau tidak dikontrol, bisa terlena juga, dan ketika terlena, kualitas itu menjadi menurun. Dengan demikian, adanyapenilaianKepalaSekolah/Supervisi adalah untuk menjaga kualitas dan untuk meningkatkan mutu sekolah.

\section{E. Pembahasan Hasil Penelitian}

Beberapa strategi yang dilakukan oleh SDI Taruna Surabaya dalam membina iklim dan budaya sekolah untuk meningkatkan kualitas pembelajaran, yang dapat diidentifikasi oleh peneliti antara lain adalah penerapan kurikulum adaptif. Mendongkrak prestasi sekolah juga menjadi strategi membina iklim dan budaya seklah di SDI Taruna. Strategi lain yang dilakukan adalah pelibatan masyarakat sekitar dan pendayagunaan potensi lokal. Penyediaan sarana-prasarana atau fasilitas layanan juga menjadi strategi yang diterapkan dalam membina iklim dan budaya sekolah di SDI Taruna. Hal lain yang dilakukan sebagai strategi untuk membina iklim dan budaya sekolah lagi adalah menjalin kerjasama dengan pihak luar.

Dalam konteks ini, SDI Taruna tidak mengembangkan program akselerasi, dengan alasan, tidak ada jaminan lulusan program akselerasi itu lebih kompeten dan lebih unggul dibandingkan dengan lulusan program reguler. ${ }^{28}$ Dengan dasar ini, program pembelajaran yang dikembangkan di SDI Taruna dilakukan secara reguler,

\footnotetext{
${ }^{27}$ Nur Mantoko (Kepala Unit Penjamin Mutu-UPM SMA Khadijah), Wawancara pada 14 Januari 2015. ${ }^{28}$ Muchammad Mas'ud (Kepala Sekolah SMA Khadijah), Wawancara pada 13 Januari 2015.

84 | Lailatu Zahroh, Strategi Kepala Sekolah dalam Pembinaan Iklim dan Budaya Sekolah di SDI Taruna Surabaya P a g e
} 
sebagaimana sekolah pada umumnya. Jadi ukuran unggul dan kompetitifnya output siswa bukan karena cepatnya, tetapi karena prestasinya.

Strategi yang dilakukan kepala SDI Taruna Surabaya dalam membina iklim dan budaya sekolah untuk meningkatkan kualitas belajar dan mutu sekolah -salah satunya- adalah mendongkrak prestasi belajar. Belajar pada hakikatnya merupakan usaha sadar yang dilakukan individu untuk memenuhi kebutuhannya. Setiap kegiatan belajar yang dilakukan siswa akan menghasilkan perubahan-perubahan dalam dirinya. Bloom dan kawan-kawan mengelompokkan domain belajar kedalam kawasan kognitif, afektif dan psikomotorik.

Prestasi belajar dipengaruhi oleh banyak faktor, seperti intelegensi, minat, sikap dan motivasi. Intelegensi merupakan salah satu faktor yang berpengaruh terhadap tinggi rendahnya prestasi belajar. Intelegensi merupakan dasar potensial bagi pencapaian hasil belajar, artinya hasil belajar yang dicapai akan bergantung pada tingkat intelegensi, dan hasil belajar yang dicapai tidak akan melebihi tingkat intelegensinya. Semakin tinggi tingkat intelegensi, makin tinggi pula kemungkinan tingkat hasil belajar yang dapat dicapai. Jika intelegensinya rendah, maka kecenderungan hasil yang dicapainya pun rendah. Meskipun demikian, tidak boleh dikatakan bahwa keika taraf prestasi belajar di sekolah kurang, pastilah taraf intelegensinya kurang, karena banyak faktor lain yang mempengaruhinya.

Prestasi belajar juga dipengaruhi oleh waktu (time) dan kesempatan (engagement). Waktu dan kesempatan yang dimiliki oleh setiap individu berbeda sehingga akan berpengaruh terhadap perbedaan kemampuan siswa. Dengan demikian, siswa yang memiliki banyak waktu dan kesempatan untuk belajar cenderung memiliki prestasi belajar yang tinggi. Para ahli mengungkapkan bahwa kepandaian seseorang itu sangat ditentukan oleh waktu dan kesempatan. Setiap orang akan mampu mengerjakan sesuatu asal diberi waktu dan kesempatan yang cukup untuk mengerjakannya. Dengan kata lain, orang pandai dapat mengerjakan banyak hal dalam waktu dan kesempatan yang relatif singkat, sementara orang bodoh membutuhkan waktu dan kesempatan yang banyak. Sehubungaan dengan itu, guru 
hendaknya dapat memberikan pelayanan individual yang berbeda untuk setiap siswa, sehingga dapat mengembangkan dirinya secara optimal.

Terdapat lima cara untuk meningkatkan kemampuan membaca untuk mendongkrak kualitas belajar. Pertama, jangan biarkan para siswa membaca dengan menggunakan pensil atau tangan untuk menunjuk kata-kata yang dibaca, karena hal ini akan memperlambat proses membaca. Siswa cukup membaca dengan mata saja; kedua, jagalah para siswa agar tidak menggerakkan bibir atau mulut pada saat membaca; ketiga, jangan biarkan para siswa menggerakkan kepalanya (ke kanan ke kiri) pada saat membaca; keempat, ajarkan para siswa cara membaca secara agresif dan aktif; kelima, ajarkan para siswa cara membaca cepat (skimming).

Dalam hal mendongkrak prestasi belajar, ada hal-hal yang perlu diperhatikan, antara lain: Pertama, hendaknya dibentuk kelompok belajar, karena dengan belajar bersama siswa yang kurang paham dapat diberitahu oleh yang telah paham dan yang telah paham dapat meningkat pemahamannya, karena menerangkan kepada temannya; kedua, semua pekerjaan dan latihan hendaknya dikerjakan segera dan sebaik-baiknya, karena latihan, terutama latihan ekspresi merupakan cara terbaik untuk penguasaan ilmu dan kecakapan; ketiga, mengesampingkan perasaan negatif dalam membahas atau berdebat mengenai suatu masalah, karena akan menghambat ekspresi dan mengurangi kejernihan pikiran; keempat, rajin membaca buku/majalah yang berkaitan dengan pelajaran, dengan banyak membaca, maka batas pandangan dan wawasan mengenai suatu pelajaran akan bertambah jauh dan luas; kelima, berusaha melengkapi dan merawat alat-alat belajar dengan baik; keenam, senantiasa menjaga kesehatan agar dapat belajar dengan baik, tidur teratur, makan bergizi dan cukup istirahat; ketujuh, waktu rekreasi gunakan sebaik-baiknya, terutama untuk menghilangkan kelelahan; kedelapan, untuk mempersiapkan dan mengikuti ujian harus melakukan persiapan minimal seminggu sebelumnya. ${ }^{29}$

Di SDI Taruna beragam upaya demi mendongkrak kualitas dan prestasi belajar dilakukan. Mulai dari kedisiplinan, pemberlakuan kurikulum adaptif, menjalin kerjasama, pembinaan secara intensif, pemberian award bagi yang berprestasi dan

\footnotetext{
${ }^{29}$ Schwartz, dalam E.Mulyasa, Manajemen \&Kepemimpinan .....hlm 98.

86 | Lailatu Zahroh, Strategi Kepala Sekolah dalam Pembinaan Iklim dan Budaya Sekolah di SDI Taruna Surabaya P a g e
} 
punishment bagi yang tidak maksimal kerjanya, uji kendali mutu, penyediaan fasilitas layanan belajar yang memadai, dan lain sebagainya.

Strategi lain yang dilakukan SDI Taruna dalam membina iklim dan budaya sekolah adalah pemanfaatan lingkungan sebagai sumber belajar atau melibatkan masyarakat dalam aktifitas sekolah. Dalam istilah lain, strategi ini bisa disebut dengan strategi pendayaan lingkungan sekitar sekolah. Pendayagunaan lingkungan sekitar sekolah merupakan suatu pendekatan pembelajaran yang berusaha untuk meningkatkan keterlibatan siswa melalui pendayagunaan lingkungan sebagai sumber belajar. Pendekatan ini berasumsi bahwa kegiatan pembelajaran akan menarik perhatian siswa bila apa yang dipelajari dari lingkungannya, sehingga apa yang dipelajari berhubungan dengan kehidupan dan berfaedah bagi lingkungannya.

Dalam pendekatan lingkungan, pembelajaran disusun sekitar hubungan dan faedahnya. Isi dan prosedur disusun hingga mempunyai makna dan ada hubungan antara siswa dengan lingkungannya. Kompetensi yang dikembangkan harus memberi jalan keluar bagi siswa dalam menanggapi lingkungannya. Pengembangan kompetensi dasar seyogyanya ditentukan oleh kebutuhan lingkungan siswa. Misalnya, di lingkungan petani, kompetensi yang berkaitan dengan pertanian akan memberikan makna yang lebih mendalam bagi para siswa. Demikian halnya di lingkungan pantai, kompetensi tentang kehidupan pantai akan sangat menarik minat dan perhatian siswa.

Di SDI Taruna, lingkungan yang dominan mengitarinya adalah lingkungan metropolitan (perkotaan) yang mana pengaruh pergaulan sekitar cenderung bebas. Oleh karenanya, SDI Taruna mengedepankan iklim dan budaya santun dan membiasakan moral keagamaan dalam pembelajarannya. Siswa siswi dibiasakan untuk mengasah nalar spiritualitasnya melalui pembiasaan tradisi atau kultur keagamaan ala nahdhiyah.

Belajar dengan pendekatan lingkungan berarti siswa mendapatkan pemahaman dan kompetensi dengan cara mengamati dan melakukan secara langsung apa-apa yang ada dan berlangsung di lingkungan sekitar, baik rumah maupun sekolah. Dalam hal ini, siswa dapat menanyakan sesuatu yang ingin diketahui pada orang lain di lingkungan mereka yang dianggap kompeten tentang masalah yang dihadapi. 
Di SDI Taruna , dunia kewirausahaan tidak begitu dikelola oleh pihak sekolah, kecuali hanya menyediakan kantin bagi yang berkepentingan. Pihak sekolah tidak mengelola persoalan kewirausahaan untuk menambah income sekolah. Pihak sekolah juga tidak mengedepankan aspek kewirausahaan menjadi bekal utama siswa siswinya.

Padahal, saat ini banyak sekolah swasta yang maju dan kualitasnya lebih baik dibanding sekolah negeri, karena tidak terikat oleh alokasi dana dari pemerintah. Mereka berusaha menambah alokasi dana sekolah melalui upaya kewirausahaan. Hal tersebut menantang sekolah negeri untuk mampu mandiri seperti sekolah swasta. Oleh karena itu, kepala sekolah harus memahami prinsip kewirausahaan, kemudian mengembangkan serta memasukkannya dalam kurikulum.

Sekolah boleh jadi menjadi unit layanan masyarakat yang diperlukan. Oleh karena itu, kepala sekolah harus mampu menjaga dan meningkatkan kualitas sekolah. Jika kualitas sekolah baik, masyarakat khususnya orang tua akan bersedia berperan aktif di sekolah, karena yakin anaknya akan mendapat pendidikan yang baik. Di sanalah pentingnya pribadi wirausaha kepala sekolah, untuk mencari jalan meningkatkan kualitas sekolah agar masyarakat dan orang tua percaya terhadap produktifitas sekolah, dan mau berpartisipasi dalam berbagai program dan kegiatan sekolah. Kepala sekolah yang demikian disebut pemimpin yang kreatif.

\section{F. Kesimpulan}

Beberapa kesimpulan yang dapat disampaikan d sini adalah sebagai berikut:

1. Strategi yang dilakukan oleh SDI Taruna Surabaya dalam membina iklim dan budaya sekolah untuk meningkatkan kualitas pembelajaran, yang dapat diidentifikasi oleh peneliti antara lain adalah: penerapan kurikulum adaptif, mendongkrak prestasi sekolah (siswa maupun guru) pelibatan masyarakat sekitar dan pendayagunaan potensi lokal, penyediaan sarana-prasarana atau fasilitas layanan, dan menjalin kerjasama dengan pihak luar dan dalam negeri.

2. Beberapa faktor pedukung kepala SDI Taruna dalam membina iklim dan budaya sekolah antara lain adalah: adanya kerjasama yang baik dengan para guru dan tenaga kependidikan berdasarkan kompetensinya, kedisiplinan para civitas akademik SDI 
Jurnal Keislaman, Vol 3, No 1

Taruna , sarana prasarana yang memadai, siswa-siswi yang kooperatif dalam menerima tata tertib sekolah, kegiatan-kegiatan ekstrakurikuler, jaringan kerjasama dengan pihak luar, dukungan masyarakat sekitar.

3. Dalam membina iklim dan budaya sekolah di SDI Taruna, kendala yang dihadapi relatif tidak begitu dominan. Kendala yang dihadapi oleh SDI Taruna antara lain: ketika ada peluang bagi siswa untuk mengikuti kegiatan di luar kota karena kompetensi yang dimiliki, terkadang tidak diizinkan oleh orang tuanya. Ada yang karena tidak punya biaya untuk uang saku anaknya, ada yang karena keberatan secara psikologis, dan ada yang karena alasan lain. Kendala lain yang terkadang dihadapi oleh SDI Taruna dalam membina iklim dan budaya sekolah adalah sedikit ada resistensi dari guru ketika ada penilaian/supervise KepalaSekolah. Padahal penilaian terhadap kinerja guru dilakukan bukan untuk maksud yang buruk, tetapi untuk maksud yang baik dan mulia, yakni untuk mengontrol kualitas (quality control)kinerja guru.

\section{DAFTAR PUSTAKA} 2012).

E.Mulyasa, Manajemen \& Kepemimpinan Kepala Sekolah (Jakarta: Bumi Aksara,

Ahmad Tafsir, Ilmu Pendidikan dalam Perspektif Islam ( Bandung: Remaja Rosdakarya, 1991).

Bogdan dan Steven, Introduction to Qualitative Research; A Phenomenological Approach to The Social Sciences (New York: John Wiley \& Sons Inc., 1975). 1990).

John White, Educational and The Good Life (London: Educational Studies Kogan,

Lexy J. Moleong, Metodologi Penelitian Kualitatif, Cet. III (Bandung: Remaja Rosda Karya, 1991). 1985)

Lincoln \& Guba, Naturalistic Inquiry (Beverly Hill: CA, SAGE Publications, Inc.,

Majalah Nahdlatul Ulama, Aula Bulan September, (Surabaya: Pengurus Wilayah Nahdlatul Ulama Jawa Timur, 2001).

Miles \& Huberman, Qualitative Data Analysis (London: SAGE Publications, 1984).

Nasution, Metodologi Penelitian Naturalistik Kualitatif (Bandung: Transito, 1996)

Noeng Muhadjir, Metodologi Penelitian Kualitatif(Yogyakarta: Rake Sarasin, 2000). 89 | Lailatu Zahroh, Strategi Kepala Sekolah dalam Pembinaan Iklim dan Budaya Sekolah di SDI Taruna Surabaya P a g e 
Jurnal Keislaman, Vol 3, No 1

Pamela Maycut \& Richard House, Beginning, Qalitative Researc, A Philosophy and Practical Guide, (Wasington D.C: The Falmer Press Teachers Library, 1994)

Robert Yin, Case Study Research (London: Sage Publications, 1989)

Undang-undang Republik IndonesiaNo 20 Tahun 2003 tentang Sistem Pendidikan Nasional (Sisdiknas), (Jakarta: Sinar Grafika)

90 | Lailatu Zahroh, Strategi Kepala Sekolah dalam Pembinaan Iklim dan Budaya Sekolah di SDI Taruna Surabaya P a g e 